\title{
Jurisprudence Analysis on the Investigative Power of Supervisory Committee
}

\author{
Qin Yuanyuan \\ School of Law, Jiangsu University, Zhenjiang, China
}

Email address:

superarc@ujs.edu.cn

To cite this article:

Qin Yuanyuan. Jurisprudence Analysis on the Investigative Power of Supervisory Committee. International Journal of Law and Society. Vol. 3, No. 4, 2020, pp. 168-171. doi: 10.11648/j.ijls.20200304.13

Received: October 14, 2020; Accepted: October 29, 2020; Published: November 9, 2020

\begin{abstract}
The construction of any legal system is based on a certain legal theoretical basis. The supervisory committee system is also established based on specific jurisprudence logic. Examining the jurisprudence logic behind the supervisory committee system can also reveal the nature of the supervisory committee's investigative power from another aspect. The status and functions of the supervisory committee are established in accordance with the constitution, and the investigative power of the supervisory committee is inherently related to the criminal procedure system. The investigative power of the Supervisory Committee is in an advantageous position in the structural system of power restriction. However, in the process of the Supervisory Committee's exercise of its investigative power, there is still room for exploration and improvement of the rights protection mechanism of the investigated objects. When judging the attributes of the supervisory committee's investigative power, on the one hand, we must pay attention to theoretical analysis, and on the other hand, we must pay attention to actual observations at the system level. It is necessary to scientifically learn from the Western rule of law theory and academic logic as analytical tools, but also to base itself on the political and ethical connotation of the innovative design of the supervision system with Chinese characteristics. Whether it is from the perspective of the constitutional system, criminal procedure system, or jurisprudence, although this kind of supervisory power as the fourth state power has rich and complex connotations, it covers the power of administrative power, judicial power, and even political power to a certain extent. It has different characteristics from governance power, but both should regard supervisory power as a fourth type of state power alongside legislative power and administrative power. As one of the basic contents of the supervisory power, the supervisory committee's investigative power, although it crosses the administrative investigation power, judicial investigation power, and disciplinary investigation power, its basic attribute is the supervisory investigation power.
\end{abstract}

Keywords: Supervisory Committee, Power of Investigation, Jurisprudence

\section{Introduction}

Any legal system is constructed on a certain legal theory. Similarly, the supervisory committee system is also constructed on the specific jurisprudence logic. In order to study the legal logic behind the system of supervisory committee, this paper aimed to reveal the attribute of the investigation power of supervisory committee from another aspect.

In jurisprudence, the power is inspected based on the logical assumption that human nature is evil. [1] The modern jurisprudence, based on the western classical natural law thought, holds that the evil nature of human nature determines that the person in charge of power is bound to abuse power and use power for personal gain in order to realize his evil nature. Montesquieu, a French enlightenment thinker and representative of classical natural law thought, famously said: "All those who have power are easy to abuse power. [2] This is an enduring and difficult experience. People with power use their power until they meet a boundary." In order to stop the abuse of the inherent power, the thinkers of classical natural law came up with two ways. One is to eliminate the abuse of power through mutual restriction between powers. Montesquieu divided power into legislative power, executive power and judicial power, and realized the restriction among legislative power, executive power and judicial power through constitutional monarchy, which could guarantee people's freedom, and reached the balance of power through mutual 
restriction among the three powers, so as to eliminate the abuse of power. [3] The second is to weaken the erosion of power by highlighting civil rights. In the eyes of classical social thinkers, power comes from the transfer of civil rights, and civil rights restrict power with natural legitimacy. For example, Rousseau, in his book The Social Contract, clearly put forward the theoretical hypothesis that rights are derived from the transfer of public contract. [4]

Following the above two logical thinking of eliminating the abuse of power in classical natural law, modern jurisprudence generally advocates that the state power should be checked and balanced by the system and supervised by the people, so as to realize the goal of "bringing power into the cage of the system" and prevent, reduce and eliminate the possibility of the abuse of power. My country's current "Constitution" stipulates a socialist political system, which is different from the Western constitutional system However, it is generally believed that the current constitution of our country is still based on the division of state power. The division of state power itself has a certain degree of power restriction implication. Therefore, to a certain extent, China's current legal system also advocates the mutual restriction of power through institutional checks and balances. As a kind of state power, the investigative power of supervisory commission should follow the same logic naturally. That is, on the one hand, the mutual restriction between the power of other states and the investigative power of supervisory Commission can be realized through institutional and institutional arrangements, so as to prevent, reduce and eliminate the possibility of abuse of the investigative power of supervisory Commission. On the other hand, the possibility of abuse of the supervisory Committee's investigative power can be prevented, reduced and eliminated by entrusting the people with the supervision of the supervisory Committee's investigative power, especially by entrusting the right relief means to the investigated objects. Therefore, it is the ontological mission of jurisprudence to analyze and explain the checks and balances and supervision mechanism of supervisory commission's investigation power from the dimension of necessity of legal theory.

\section{The Status of the Supervisory Committee's Investigative Powers}

Compared with other state powers of the same rank, the investigative power of supervisory commission has certain advantages. In other words, the investigative power of supervisory committee is in a dominant position in the structural system of power restriction.

1) in the aspect of duty crime investigation, the supervision of procuratorial organs on the investigation power of supervisory committee is generally weak. According to the Constitution, the procuratorial organs and supervisory commissions are the state legal supervision organs and supervisory organs respectively. On the one hand, in accordance with the relevant provisions of the Criminal
Procedure Law, the supervisory Commission, although not in the name of exercising the power of criminal investigation, has to some extent the practice of exercising the power of criminal investigation. [5] For example, article 170 (2) of the newly amended Criminal Procedure Law stipulates that in cases where the supervisory organ has transferred the suspect for prosecution and has taken lien measures, the people's Procuratorate shall detain the criminal suspect first, and shall make a decision on whether to arrest, obtain a guarantor pending trial or place him under residential surveillance within 10 days after the detention. The terms of this new increase, it is a response to "inspect" article 47 (1) and refinement, from the legal level to perfect the criminal procedure law and the inspection act of cohesive mechanisms, but also from the system operating level to achieve the right of the procuratorial organs' supervision of such investigations in supervisory committee duties crime. [6] In addition, the law also grants the supervisory organs the right of reconsideration in reviewing the prosecution. As the fourth paragraph of Article 47 of the Supervision Law provides, "Where a people's procuratorate does not initiate a prosecution under the circumstances prescribed in the Criminal Procedure Law of the People's Republic of China, it shall, upon approval by the people's Procuratorate at the next higher level, decide not to initiate a prosecution in accordance with the law. If the supervisory organ considers that the decision not to prosecute is wrong, it may apply to the people's procuratorate at the next higher level for reconsideration." According to Article 179 of the newly revised Criminal Procedure Law, "If a people's procuratorate decides not to prosecute a case transferred by a public security organ, it shall deliver the decision in writing to the public security organ. If the public security organ considers that the decision not to bring a suit is wrong, it may request a reconsideration. If the opinion is not accepted, it may apply to the people's procuratorate at the next higher level for review." It can be seen that the same is the case that the procuratorial organ decided not to prosecute after being transferred for prosecution, the public security organ transferred for prosecution and the supervisory Commission transferred for prosecution of treatment there is an obvious difference. According to the provisions of paragraph 4 of Article 47 of the Supervision Law, if a procuratorial organ decides not to prosecute a case transferred by a supervisory Commission, it shall first obtain the approval of the procuratorial organ at a higher level. For the cases transferred to prosecution by the public security organs, the decision not to prosecute can be made directly, less the procedure approved by the procuratorial organs at higher levels. There is also a gap in the treatment of relief procedure after the decision of non-prosecution. In other words, procuratorial organs conduct procuratorial supervision over the investigation of public security organs through examination and prosecution, which is obviously stricter than the investigation of work-related crimes conducted by supervisory committees. [7] For another example, in accordance with the provisions of article 15, paragraph 1 of the Supervision Law, the procuratorial organ as the legal supervision organ is itself the supervision object of 
the supervision organ. This regulation also strengthens the preponderance position of investigative power of supervisory committee to a certain extent. At the same time, this regulation also caused the academic controversy and the discussion. After the amendment of the Criminal Procedure Law, some scholars called for adherence to the position of the procuratorial organs as legal supervision organs. "Against this background, we should unswervingly adhere to the constitutional position of the legal supervision of the procuratorial organs, ensure that the procuratorial organs independently exercise the power of procuratorial supervision in accordance with the law under the new situation, and distinguish the concepts of procuratorial supervision, litigation supervision, legal supervision and supervision, which cannot replace each other, let alone be mixed together."[8]

2) At the level of political system, supervisory power has a certain priority compared with legislative, executive and judicial power. The "constitution" in paragraph 3, article 3, paragraph 1 of article one hundred and twenty-three, article one hundred and twenty-three and article 8 of the inspection act, and many other legal norms, exercise the supervisory authority of national supervision committee was established as the National People's Congress, and the state institutions responsible for the National People's Congress, the state supervisory committee and the exercise of executive power is the supreme state council, exercise the highest judicial power of the Supreme Court and the Supreme People's Procuratorate tied for the National People's Congress, under the leadership of the supervisory authority as the supreme organ of power and legislative power, executive power and judicial power tied for fourth state power. [9] But unlike the State Council, which exercises the highest executive power, the Supreme Court and the Supreme People's Procuratorate, which exercise the highest judicial power, the National Supervisory Commission does not report its work to the NPC during its term. This article believes that this is precisely the performance of the People's Congress to weaken the supervisory authority of the supervisory committee. The People's Congress wants to weaken the supervision of the board of supervisors in order to maintain all the powers of the board of supervisors co-signed with the party's discipline inspection committee. [10] So far, "my country's supervisory power has been completely separated from the government's administrative power and has become a secondary power alongside executive power and judicial power." It has become the fourth state power alongside legislative power, administrative power, and judicial power. [11] In fact, the Supervisory Committee and the Party's Disciplinary Inspection Committee have been highly integrated in the process of exercising procuratorial power, and it is difficult to separate them.

\section{Improvement of the Supervisory Committee's Investigative Powers}

In the process of the supervisory Commission exercising its power of investigation, there is still room for exploration and improvement in the relevant provisions of the Supervision Law and the Criminal Procedure Law concerning the protection mechanism of the investigated objects.

1) In the design of supervisory committee system, there is room for the way to protect the rights of the investigated objects For example, the supervision Law, the Criminal Procedure Law and other relevant provisions do not clearly define the right of lawyers to intervene in the investigation stage of duty crimes by supervisory commissions. The first paragraph of Article 34 of the newly revised Criminal Procedure Law contains the provisions that "a criminal suspect shall have the right to entrust a defender from the date when he is interrogated for the first time by an investigation organ or when compulsory measures are taken". However, "supervision Law" in the relevant supervisory committee investigation procedures of the provisions, the illegal investigation and criminal investigation mixed provisions, after the initial examination of the case procedures, that is, investigation can be launched, but cannot determine whether it is illegal investigation or criminal investigation. "The way of handling cases under supervision blurs the boundary between 'illegal investigation' and 'criminal investigation', and it is difficult to judge when the investigation has entered the stage of 'criminal investigation' with the nature of investigation." [12] Unable to accurately determine the starting time of the duty crime investigation, investigation measures against illegal investigation or on duty crime investigation, judgments, thus constituted "criminal procedural law" the first paragraph of article 34 of the applicable law of technical barriers, prevented respondents by applicable "criminal procedural law" the first paragraph of article 34 of get a lawyer to help, the lawyer cannot intervene.

2) In terms of the operation mechanism of the power of investigation of supervisory Committee, there is space for exploration of the right relief methods of the investigated objects. Although the design goal of investigation power is to cover all public power, according to the actual situation of our country, the vast majority of respondents are CPC members, especially leading cadres at all levels of the Party. In addition to obeying national laws, such people are subject to a range of party rules and regulations. And party regulations are generally considered to be based on party members' obligations rather than their rights. [13] This is because "party laws and regulations, dominated by the obligations of party members, are an inherent requirement for implementing the party's purposes and safeguarding the party's interests." [14] At the same time, compared with the requirements of national laws for citizens, inner-Party laws and regulations put forward more norms of obligations for party members and set higher standards of morality and discipline. On the one hand, this reflects the party's discipline requirements, but on the other hand, it may easily lead to the weakening of the right relief as an ordinary citizen.

\section{Conclusion}

After the completion of the reform of the supervision 
system in our country on the basis of pilot projects, the supervision committee system was confirmed in the form of the constitution, and the Supervision Law "established a single track that integrates party disciplinary investigation power, political disciplinary investigation power and criminal investigation power. Investigation system." [15] So far, my country has realized the supervision power, especially the investigative power at the core of the supervision power, covering all public powers. This is a major breakthrough in the reform of the supervision system and a fundamental sign of the successful transformation of the supervision system. The power of supervision is granted by the constitution and is exercised in accordance with the "Supervision Law". Its legal status is listed in the legislative power, administrative power, and judicial power. The power of supervision is the power of supervision and investigation that is side by side with the legislative power, administrative power, and judicial power. It is derived from the power of supervision. Although it has the characteristics of the power of inspection and investigation, the power of supervision and investigation has its own specific connotation and extension. The power of supervision and investigation is not equivalent to the power of prosecution and investigation. The newly revised Criminal Procedure Law also makes a strict distinction between the two. That is, at the level of system operation, although the power of supervision and investigation crosses the power of administrative investigation, judicial investigation and violation of discipline The power of investigation, but its basic attribute is the power of supervision and investigation, which is a new type of state power.

The practice of the supervisory system calls for theoretical responses. Under the overall framework of the socialist system with Chinese characteristics in the new era, the reform and development of the supervisory system require a unified understanding of the socialist rule of law with Chinese characteristics, and to grasp and handle the relationship between norms and behavior in the operation of supervisory power. The power of supervision is a "new thing" born with the reform of the supervision system. It needs to be tested and baptized in practice, and explored on the basis of accumulated experience. Similarly, The supervision and investigation power and the practice of the supervision system require profound interpretation and analysis of legal theory in order to seek the legal foundation and value foundation for its effective operation. In the legal theory system, jurisprudence studies basic legal phenomena such as law, legal thought, and legal systems from the perspective of dialectical materialism and materialist dialectics, and has a methodological guiding significance for all branches of law. Therefore, analyzing and thinking about the nature and characteristics of the power of supervision and investigation from the perspective of jurisprudence, as well as the existing problems in the process of exercising the power, have both theoretical significance and practical guidance value.

\section{References}

[1] Yuan Baishun, Yao Xiaobo. Constitutional Thinking on the Evil Hypothesis of Human Nature-Balance of Freedom and Power. Journal of Sichuan dministration Institute, No. 2, 2010.

[2] Montesquieu. "The Spirit of Law", Beijing: Contemporary World Press, 2008, PP. 76.

[3] Wu Kejiao. On the Enlightenment of Montesquieu's Thought of the Separation of Powers to my country's Power Check and Balance. Journal of Jiamusi Vocational Institute, No. 8, 2018.

[4] Chen Yu. The "right" of power or the "power" of right-analysis of the relationship between power and right. Forward Position, No. 1, 2009.

[5] Liu Yanhong. Examination and exclusion of illegal evidence in duty crime cases: in the context of the "Supervision Law" and the "Criminal Procedure Law". Law Review, No. 1, 2019.

[6] Xu Hanming. A Probe into the Attributes of State Supervision Power. Law Review, No. 1, 2018.

[7] Li li. On the Reasonable Construction of my country's Investigation and Supervision System. Law Science Magazine, No. 3, 2009.

[8] Fan Chongyi. Interpretation of the latest amendments to the Criminal Procedure Law in 2018. China Law Review. NO. 6, 2018.

[9] Zheng Junxian. On the Investigation Power of the Board of Supervisors. China Law Review, No. 4, 2017.

[10] Tong Zhiwei. A strategy to bring the reform of the supervision system into the track of the rule of law. Law Science, No. 12, 2016.

[11] Hong Hao, Zhu Liang. Lien of the Supervisory Commission: power attributes, operational principles and procedures. Journal of Gansu Political Science and Law Institute, No. 2, 2019.

[12] Chen Weidong. Researches on Several Issues Relating to Investigative Procedure of Duty-related Crime Supervision. Political Science and Law. NO. 1, 2018.

[13] Zuo Weimin, An Qi. Supervising and investigating power: consideration of nature, exercise and regulation. Wuhan University Journal (Philosophy \& Social cience), No. 1, 2018.

[14] Wu bing. On the Realization Path of Strictly Governing the Party in an All-round Way-Based on the Perspective of Party Members' Rights and Obligations and the Power Relationship within the Party. Journal of Xinxiang University. NO. 11, 2018.

[15] Chen Ruihua. On the Investigation Power of Supervisory Committee. Journal of Renmin University of China, No. 4, 2018. 